\title{
Proč jedná sociální pracovník fanaticky, cynicky, nebo vyrovnaně? K souvislostem mezi spiritualitou a morálním postojem $\mathrm{k}$ tomu, co nelze změnit Vojtěch Šimek
}

\section{Úvodem}

Spiritualita je pro sociálního pracovníka / sociální pracovnici (dále „SP“) významná. V českém myšlenkovém prostoru to dokládá přehledová studie Postavení diskursu spirituality v sociální práci zveřejněná v roce 2015. Stručně mapuje proměny vztahu sociální práce ke spiritualitě, a to jak v USA, tak i u nás. ${ }^{1}$ Omezíme-li se na ČR, najdeme ve studii kromě jiného toto klíčové zjištění: od roku 2008 u nás nabývá diskurs spirituality v sociální práci na stále větším významu. ${ }^{2}$ Jedním z teoretických projevů může být kuprŕkladu monografie z roku 2012 s názvem Spiritualita v pomáhajících profesích. ${ }^{3}$ Co se týká empirických výzkumů, zmiňme stat Fenomén spirituality a jeho integrace do osnov sociální práce z roku $2010,{ }^{4}$ která ukazuje důležitost tématu spirituality nejen pro SP, ale už pro studenty sociální práce. Stat končí výzvou: „Úkolem stojícím dnes před akademiky je nebát se se studenty [sociální práce] o spiritualitě hovořit, zároveň je nutné najít způsob, jak začlenit do kurikula obsah, který (...) vybaví budoucí [SP] způsobilostí co nejlépe reagovat na potřeby klientů. “5

Hovořit a přemýšlet o spiritualitě je však možné jen natolik, nakolik pojem „spiritualita“ vymezíme. V jakém významu zde pojem „spiritualita“ používám? Zmíněná studie rozlišuje s ohledem na SP tzv. „sekulární spiritualitu“ a tzv. „sacred spiritualitu“. V prvním př́padě se jedná o spiritualitu, pro niž není vztah k Posvátnu/Bohu podmínkou. V druhém př́ípadě je tomu naopak. Za pozornost stojí, že podstatnou charakteristikou sekulární spirituality je podle studie „hledání smyslu života“. Zároveň se v této souvislosti ve studii objevuje myšlenka, že v tomto významu má

\footnotetext{
Jan KAŇÁK, Postavení diskursu spirituality v sociální práci, Sociální práce / Sociálna práca 4/2015, s. 30-46.

Srov. tamtéž, s. 41-42.

Zdeněk VOJTÍŠEK - Pavel DUŠEK - Jiří MOTL, Spiritualita v pomáhajících profesích, Praha: Portál, 2012.

Alina KUBICOVÁ, Fenomén spirituality a jeho integrace do osnov sociální práce, in: Rizika sociální práce, ed. Martin SMUTEK Friedrich W. SEIBEL - Zuzana TRUHLÁŘOVÁ, Hradec Králové: Univerzita Hradec Králové, 2010, s. 459-464.

5 Tamtéž, s. 464.

6 Spiritualita bývá v současnosti někdy zjednodušeně chápána jako protiklad religiozity. Spiritualita je podle tohoto chápání čistě individuální a neinstitucionální projev vztahu osoby ke Smyslu/Transcendenci/Posvátnu/Bohu, zatímco religiozita jako čistě společenská a institucionální př́slušnost $\mathrm{k}$ nějaké duchovní tradici / náboženství / církvi. Zde vycházím z toho, že obsahy pojmů „spiritualita“ a „religiozita“ se naopak zpravidla překrývají. Tedy že „religiozita [je často] podmnožinou spirituality, (...) jedním (nejvýraznějším, relativně snadno zachytitelným a obvykle zkoumaným) [projevem] spirituality.“ Spiritualita nějaké osoby bývá zpravidla „sycena v celé své šíři z jedné duchovní tradice ( $\mathrm{z}$ jednoho náboženství)“, je ale samožrejmě možné (a v současném západním světě rozšířené), že něčí osobní spiritualita se nekryje (zcela/vůbec) s př́slušností k nějaké duchovní tradici / náboženství / církvi. Může tudíž existovat i spiritualita bez religiozity, ale také (přinejmenším hypoteticky) i religiozita bez spirituality. K tomu více Zdeněk VOJTÍŠEK, Spiritualita, in: Zdeněk VOJTÍŠEK - Pavel DUŠEK - Jiří MOTL, Spiritualita v pomáhajících profesích, s. 25-31.
} 
spiritualitu vlastně každý, „protože hledání smyslu je vlastní všem lidem.“7 Z toho lze vyvodit: spiritualita ve významu hledání smyslu života, byt třeba implicitně a nevědomky, je vlastní všem SP, protože každý SP je člověk. Autor studie takový závěr explicitně nevyvozuje. Pro tento článek je však prvním krokem k vymezení pojmu spirituality, jak jej používám.

Někdo by však mohl namítnout: Hledání smyslu života není vlastní všem lidem, příp. ne všem SP. A i kdyby tomu tak bylo, pak to není pro vymezení spirituality vhodné východisko. Na první námitku lze asi nejlépe odpovědět odkazem na Franklův koncept vůle ke smyslu. Frankl, profesor neurologie a psychiatrie, tvrdí, že vi̊le ke smyslu je fundamentálně antropologický fenomén, tedy nejen platný pro všechny lidi, ale navíc esenciální atribut lidství a potřeba sui generis, empiricky potvrzená. ${ }^{8}$ První námitka se tedy zdá irelevantní. Je ale vůle ke smyslu vhodným východiskem pro vymezení spirituality?

Vyjdeme-li z Franklova konceptu, lze odpovědět kladně. Podle Frankla je vưle ke smyslu jedním z obecných aspektů sebetranscendence člověka. ${ }^{9}$ A jestliže je sebetranscendence člověka podstatným vyjádření jeho spirituality, pak je vi̊le ke smyslu obecně platným aspektem spirituality. Miloš Raban, nedávno zesnulý český znalec Franklova díla, jde ještě dále a tvrdí, že pojmy smyslu (života) a spirituality koincidují, „vyjadřují nakonec totéž. “10 S pojmem „spiritualita SP“ tedy ve svém článku pracuji v tomto jeho obecně platném významu - hledání objektivního smyslu života. I když Frankl chápal smysl také jako subjektivní, jedinečný pro každou osobu a situaci, přesto zdůrazňoval, že smysl života se nedá „vytvořit“, ale je nutné jej „najít“. života jakožto centrální aspekt spirituality SP nějaké souvislosti s morálním postojem SP k tomu, co SP nemůže změnit? To je klíčová otázka.

V tomto článku vycházím z hypotézy, že takové souvislosti existují. A pokusím se ukázat, že jde o souvislosti, které jsou pro osobní praxi SP významné. Omezím se při tom na zkoumání morálního postoje SP k tomu, co nemůže změnit a vadí mu na osobě klienta (vnitřní „nezměnitelnosti“) a/nebo na situaci klienta (vnější „nezměnitelnosti“). Zkušenost nám říká, že právě to, co nemůžeme změnit a vadí nám, pro nás zpravidla představuje náročnější morální výzvu, nebot’ se většinou snažíme najít smysl dané „nezměnitelnosti“. ${ }^{12}$ Morálním postojem rozumím postoj osoby, která aktivuje své svědomí13 a přistupuje $\mathrm{k}$ daným vnitřním a/nebo vnějším „nezměnitelnostem“ také skrze osobní ctnosti či neřesti.

7 Jan KAŇÁK, Postavení diskursu spirituality v sociální práci, s. 33.

8 Srov. Viktor E. FRANKL, Utrpení z nesmyslnosti života: Psychoterapie pro dnešní dobu, Praha: Portál, 2016, s. 15. „... vůle ke smyslu reprezentuje motivaci sui generis, která se nedá redukovat na jiné potřeby ani se z nich nedá odvodit.“Více o empirickém potvrzení viz Viktor E. FRANKL, Vưle ke smyslu: Vybrané přednášky o logoterapii, Brno: Cesta, 1994, s. 11-12.

9 „Jeden aspekt sebetranscendence, zásadní fakt, že člověk sahá [nad] sebe sama k nějakému smyslu, který má být naplněn - a nejdřív vlastně vůbec odhalen, snažím se postihnout motivačně teoretickým konceptem, vůle ke smyslu“."Viktor E. FRANKL, Vưle ke smyslu, s. 11. Z hlediska filosofické antropologie je sebetranscendence jednou ze tř́ hlavních metafyzických charakteristik osoby. Norris W. CLARKE, Osoba a bytí, Kostelní Vydří: Karmelitánské nakladatelství, 2007.

10 Miloš RABAN, Duchovní smysl člověka dnes: Od objektivního k existenciálnímu a věčnému, Praha: Vyšehrad, 2008, s. 193.

11 Srov. Viktor E. FRANKL, Utrpení z nesmyslnosti života, s. 25. „Co se vytvořit dá, je bud’ subjektivní smysl, pouhý pocit smyslu - anebo nesmysl. Pak je ovšem také pochopitelné, že člověk, který už není schopen nacházet ve svém životě smysl, a zároveň není schopen jej vymyslet, že takový člověk na útěku před pocitem nesmyslnosti života plodí bud’ nesmysl, nebo subjektivní smysl. (...) vyvstává nebezpečí, že člověk svým životem projde mimo pravý smysl, mimo pravé úkoly venku ve světě (které jsou něco jiného než pouze subjektivní prožitky smyslu v sobě samotném).“

12 Tím ale nechci tvrdit, že $\mathrm{k}$ tomu, co nemůžeme změnit a nevadí nám, není možné zaujmout morální postoj a vztahovat to $\mathrm{k}$ otázce smyslu svého života. Činíme tak, často implicitně, někdy ale i explicitně. Např. jsem muž, nemohu to změnit a nevadí mi to (jsem tak dokonce spokojen). Přesto ale $\mathrm{k}$ této danosti zaujímám přinejmenším implicitně morální postoj už tím, že to přijímám jako smysluplný základ svého osobního života a rozvoje. To, co ale změnit nemohu a (z jakýchkoli důvodů) mi vadí, představuje oproti tomu morálně specifickou, náročnější výzvu, protože je obtižné to přijmout jako smysluplné východisko osobního života a rozvoje.

13 Podle Frankla je svědomí „orgán smyslu“, „součástí condition humaine“, nástroj, jímž člověk objektivní smysl života hledá a odkrývá. Viktor E. FRANKL, Utrpení z nesmyslnosti života, s. 25-26. 
Jak ale vystihnout souvislosti mezi hledáním objektivního smyslu života jakožto centrálním aspektem spirituality SP a morálním postojem SP $k$ tomu, co SP nemůže zmènit? Tohoto úkolu se pokusím dosáhnout v první části článku s pomocí inspirativní typologie německého filosofa Roberta Spaemanna. Půjde o základní typologii fanatik, cynik a vyrovnaný stoik. Typologie může sloužit studentům sociální práce či $\mathrm{SP}^{14}$ jako výchozí rámec pro sebereflexi jejich spirituality v uvažovaném centrálním aspektu. Přivedla mě $\mathrm{k}$ tomu inspirativní myšlenka českého religionisty Zdeňka Vojtiška, který ve výše uvedené monografii piše, že „ve spiritualitě jednotlivého člověka“ se nachází „zdroj jeho potíżí.“"

Co však ti SP, kteří prožívají spiritualitu ve druhém výše naznačeném významu (sacred spiritualita), tj. vztah k Posvátnu/Bohu je nutnou podmínkou jejich spirituality. Hledají i oni smysl života? Je zřejmé, že rovněž sacred spiritualita implikuje centrální aspekt týkající se smyslu života. V každém náboženství, přinejmenším ve třech největších monoteistických (judaismu, křestanství a islámu), ovšem už zpravidla nejde o hledání smyslu, ale o přijetí smyslu, který je dán tím kterým pojetím Boha. $\mathrm{V}$ tomto článku omezím sacred spiritualitu na křestanství, v němž je objektivní smysl života dán specifickým trojičním pojetím Boha a naplněn v Ježíši Kristu. Český teolog Michal Opatrný věnující se vztahu křestanské teologie a sociální práce se v jednom svém textu stručně dotýká i problematiky smyslu a má za to, že oním možným zdrojem potíži SP může být právě nespolehnutí se na Krista. ${ }^{16}$

Ve druhé části článku se proto pokusím jednak doplnit uvedenou typologii o vyrovnaného kresta$n a$ a zamyslet se nad křestanským spolehnutím na Krista, jednak s pomocí př́kladů naznačit některé souvislosti mezi spolehnutím se na Krista ze strany SP křestana a jeho morálním postojem $\mathrm{k}$ tomu, co nemůže změnit a vadí mu. I tato část nabízí výchozí rámec možné sebereflexe; tentokrát těm SP, kteři jsou křestany či se o křestanství zajímají. Křestané představují v Evropě stále silně zastoupenou skupinu a na křestanské morální principy se více či méně explicitně odvolává mnoho organizací věnujících se sociální práci.

Odborným polem tohoto článku je především filosofická a teologická antropologie a etika. Vycházím z předpokladu, že teorie sociální práce (jakožto věda) potřebuje nutně jak antropologii, tak etiku, a to i ve filosofickém a teologickém rozměru, jestliže má adekvátně zkoumat spiritualitu. Rád bych ještě na úvod doplnil: jsem si vědom, že spiritualita je komplexnífenomén. Vybral jsem si jen jeden její aspekt, který sice pokládám za centrální, není však jediný. ${ }^{17} \mathrm{Jde}$ mi o racionální aspekt spirituality, nakolik ovlivňuje volní, morální stránku osoby. ${ }^{18}$

14 Dále pro zjednodušení označuji jak sociálního pracovníka / sociální pracovnici, tak studenta/studentku sociální práce zkratkou „SP“. Uvedenou hypotézu předpokládejme pro obě skupiny, byt’ pro každou může mít jiný význam. Pro studenty především teoretický, pro pracovníky př̌edevším praktický. Pro obě skupiny je však velmi přínosné, pokud se neomezí pouze na jeden z nich. I pracovníci mají dále studovat, i studenti si mají vyzkoušet praxi v oboru, který studují.

15 Zdeněk VOJTÍŠEK, Cesty pomoci v potížích se spiritualitou, in: Zdeněk VOJTÍŠEK - Pavel DUŠEK - Jiří MOTL, Spiritualita $v$ pomáhajících profesích, s. 49. „Jako v podstatě jedinou nepřekročitelnou podmínku kvalitní pomoci tak vidíme už několikrát zmiňovanou reflexi vlastní spirituality, provedenou nejlépe s pomocí supervizora. “Tamtéž, s. 68.

16 „Křestan coby pomáhající sice může víru v Krista deklarovat, ale nemusí se přitom na něj při své práci skutečně spoléhat. Může tvrdit, že má smysl konat dobro, ale přitom se na dobro a jeho Původce nespoléhat. Pomáhající pak chce mít nad klientem absolutní kontrolu nespoléhá se na to, že smysl, který jeho samotného nese, může nést i klienta, takže klientovi nedá vůbec žádnou šanci k tomu, aby se sám nechal nést. Můžeme to říci i obráceně: Protože se pracovník nespoléhá na smysl, který nese jeho i jeho práci, nedokáže se spolehnout ani na klienta, že vykoná svěrený úkol nebo že nezopakuje svou chybu. Dle mého soudu jde v tomto ,spolehnutí se na Boha‘ o jeden z nejzásadnějších aspektů křestanské víry..." Michal OPATRNÝ, Třináctá komnata vztahu teologie a sociální práce: K problematice negativních vlivů křestanské víry na pomáhání, Caritas et veritas 1/2011, s. 57-58.

17 Vojtíšek vyjadřuje komplexnost spirituality modelem, který má 7 rovin. Mnou analyzovaný centrální aspekt odpovídá 1. rovině předpokladům spirituality („Jsou to naukové a filosofické koncepce, které člověku vysvětlují svět, poskytují orientaci v něm a dávají jeho životu (...) smysl."), co do vlivu na praxi ovšem také 3. rovině - normám a hodnotám, které určují morální postoj člověka. Kromě těchto dvou rovin zahrnuje Vojtíškův model ještě rovinu obřadů (2.), vyprávění (4.), zážitků (5.), společenství (6.) a tvořivosti (7.). Zdeněk VOJTÍŠEK, Spiritualita, in: Zdeněk VOJTÍŠEK - Pavel DUŠEK - Jiří MOTL, Spiritualita v pomáhajících profesích, s. 19-22.

18 Vojtíšek dodává, že uvedený (statický) model komplexnosti spirituality je nutné doplnit „dynamickým, volním rozměrem“ - zaujetím, 


\section{Fanatik, cynik a vyrovnaný stoik}

Dřive než se zaměřím s pomocí Spaemannovy typologie na souvislosti mezi hledáním objektivního smyslu života jakožto centrálním aspektem spirituality SP a morálním postojem SP k tomu, co SP nemůže změnit, pokusím se velmi stručně načrtnout základní druhy nezměnitelností, jimž podléhá každá lidská osoba, a také to, jak se obecně mohou promítat do sociální práce.

Každá osoba je již od početí určována vnitřními nezměnitelnostmi: jedinečnou genetickou výbavou, která implikuje určité (pre)dispozice, pohlavím apod. Mezi vnějš́ nezměnitelnosti lze zařadit biologické rodiče, čas a místo početí/narození osoby, zemi, kulturu a sociální prostředí, kde daná osoba vyrůstá a je formována apod. Výchovou a vzděláním dochází jednak k pasivně zpưsobeným nezměnitelnostem, jednak $\mathrm{k}$ aktivně ziskaným nezměnitelnostem tím, jak je osoba nejen pasivně formována, ale také jakým způsobem sebe samu aktivně utvárí. $\mathrm{Z}$ aktivního hlediska se každé minulé rozhodnutí a jednání osoby stává něčím, co nelze změnit a čím osoba sebe samu formuje $\mathrm{v}$ rámci svých vlastních vnitřních a vnějších nezměnitelností. Existují celoživotní nezměnitelnosti, např. genetické (pre)dispozice, dlouhodobé nezměnitelnosti, nap̌r. morální charakter (čím je osoba starší, tím obtížněji a déle trvá změna) a krátkodobé nezměnitelnosti, např. onemocnění chřipkou apod. Dlouhodobé a krátkodobé nezměnitelnosti někdy vycházejí z celoživotních, někdy vznikají z kombinace různých přícin a okolností. Jak jsem výše uvedl, celkově lze tyto (a další možné) druhy nezměnitelností rozdělit na ty, které dané osobě vadí, a na ty, které dané osobě nevadí. ${ }^{19}$ Z povahy sociální práce vyplývá, že se zaměřuje na sociální změnu v rámci dlouhodobých a krátkodobých nezměnitelností klientů. Je evidentní, že celoživotní nezměnitelnosti klientů nelze změnit. Mám za to, že pro sociální práci je typické úsili o změnu dlouhodobých a krátkodobých nezmènitelností $v$ rámci zpravidla nepríznivých celoživotních/dlouhodobých nezměnitelností klientů. SP nicméně mnohdy nemůže př́mo ovlivnit ani dlouhodobé nezměnitelnosti (přičemž ví, že na tom závisí zcela/částečně úspěšnost sociální práce s klientem). Zároveň se také SP často nachází v situacích, kdy mu určité, (pro daný sociální př́pad typické) dlouhodobé/krátkodobé nezměnitelnosti, vadí, zatímco klientovi třeba nikoli (jako př́klad lze uvést sociální práci s drogově závislým klientem; jeho závislost zpravidla vyplývá ze sociálního prostředí, kde daný klient žije; klientovi toto prostředí většinou nevadí, protože se v něm může cítit dobře; SP naopak vadí, protože ví, že teprve jiné prostředí klientovi umožní zbavit se drogové závislosti). Celkově lze usuzovat, že $S P$ se velmi často nacházi v situacích, kdy je konfrontován s celou řadou pro něj obtižně príijatelných celoživotních, dlouhodobých i krátkodobých nezmènitelností klientủ. Existují při tom nějaké souvislosti mezi centrálním aspektem spirituality SP, hledáním objektivního smyslu života, a jeho morálním postojem $\mathrm{k}$ daným nezměnitelnostem?

(a) Fanatik se domnívá, že smysl života existuje jen jako jím daný a jím realizovaný. Staví svůj subjektivní smysl života proti realitě a domnívá se, že žádný objektivní smysl života neexistuje.

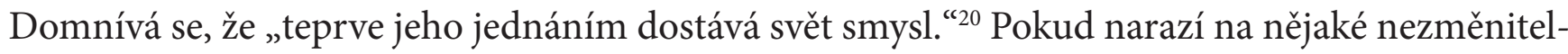
nosti, které mu vadí, zdráhá se je přijmout a zpravidla reaguje odmítnutím, popřením nebo pokusem o změnu. V morálním ohledu se stává subjektivistou. „Fanatikem je ten, kdo říká s Hitlerem:

oddaností. To naprosto odpovídá základním mohutnostem lidské osoby, jež kromě rozumu a citů disponuje vůlí. Srov. tamtéž, s. 22-23.

19 Přičemž je velmi zajímavé, že to, zda a nakolik nějaká nezměnitelnost nějaké osobě (ne)vadí, je opět dáno jejími specifickými nezměnitelnostmi, nap̌r. jejím morálním charakterem, povahou, sklony, ale také náboženským, kulturním a sociálním prostředí, $\mathrm{v}$ němž žije.

20 Robert SPAEMANN, Moralische Grundbegriffe, München: C. H. Beck, 8. vyd., 2009, s. 102. Existuje i český překlad, zde pracuji $s$ německým originálem. 
Jestliže zanikneme, ztratí světové dějiny smysl.“21

SP fanatik má velké problémy přijmout všechny druhy nezměnitelností klienta, které mu vadí. Reaguje odmítnutím, popřením, nebo neuváženým pokusem o změnu. Místo, aby nezměnitelnosti přijal a začal s nimi konstruktivně pracovat, ztrácí čas a energii jejich ignorací či popíráním, př́p. i nebezpečnými pokusy o změnu. SP fanatik je přesvědčen, že teprve on vnáší smysl do klientova života. Když klientovi „nepomůže“, ztratí život klienta zcela smysl. Morálně dochází zpravidla k nedovoleným zásahům do klientovy autonomie. Psychologicky se SP fanatik orientuje spiše na submisivní klienty, kteří SP uvěrí, že jedině on jim pomůže.

Uved’me si jednoduché príklady morálních postojů SP fanatika; první se vztahuje k vnitřní nezměnitelnosti klienta, druhý k vnější:

- SP vadí zvláštní chování klienta. Místo, aby SP přijal fakt, že klient je psychicky nemocný člověk (a začal s klientem podle toho adekvátně pracovat), více či méně tento fakt ignoruje a přistupuje ke klientovi, jako by šlo o přechodnou labilitu, přičemž zároveň klientovi sugeruje, že ji musí překonat.

- SP usiluje o odebrání dítěte z rodiny, kde jsou pro dítě sice zhoršené podmínky, ale kde má dítě zároveň obě důležité referenční osoby pro svůj normální psychický vývoj (vlastního otce a vlastní matku). SP subjektivně vadí zhoršené podmínky v domácnosti a fanaticky je považuje za důležitěǰš́ kritérium než objektivní kritérium přítomnosti otce a matky.

(b) Cynik je opakem fanatika, neklade vlastní subjektivní smysl proti realitě, ale realitu proti veškerému smyslu. $V$ jednom se ovšem s fanatikem shodují: žádný objektivní smysl života neexistuje - „skutečnost obklopující naše jednání, jež mu předchází a do níž naše jednání ústí, je beze smyslu. ${ }^{\text {"22 }}$ Podle cynika je veškeré dění založeno na náhodě, nemá smysl v ničem hledat objektivní smysl ani ničemu dávat subjektivní smysl. ${ }^{23}$ Cynik přesto paradoxně „věríi“ $v$ právo silnějšího. Pokud narazí na nějaké nezměnitelnosti, které mu vadí, reaguje zpravidla úsměškem nebo výrokem „takový už je život, nehledejme za tím nic víc“. Veškeré dění považuje za mechanické; zpravidla je přesvědčeným materialistou, $\mathrm{v}$ morálním ohledu nihilistou.

SP cynik je často „vyléčeným“ fanatikem, který postupně zjistil, že realita, proti které „bojoval“, byla silnější. Zatímco fanatik nezměnitelnosti klienta popíral, odmítal nebo se je pokoušel nebezpečně „měnit“, cynik „poučeně“ rezignoval. V prŕpadě cynika ovšem nejde o realistické přijetí klientových nezměnitelností, nýbrž o jejich banalizaci. Cynik sice neztrácí jako fanatik čas nebezpečnými pokusy o „změnu“ klientových nezměnitelností, na druhé straně čas ale neztrácí ani s klientem, protože se domnívá, že to stejně nemá smysl. Cynik je totiž přesvědčen, že vưbec nemá smysl klientovi pomáhat. I kdyby klientovi (někdo) pomohl, stejně to v dlouhodobém horizontu nezajistí úspěch. U cynika dochází morálně zpravidla k nedovolené banalizaci či nihilismu, př́íp. skepticismu. Cynik může často klienty zanedbávat, být krutý nebo dělat práci „jen naoko“. Psychologicky se SP cynik orientuje hlavně na ty klienty, kteří mu „nedělají problémy“.

21 Tamtéž.

22 Tamtéž, s. 103.

23 Proti tomu lze ovšem namítat s pomocí nekonečného regresu: Proč nemá smysl hledat/dávat něčemu smysl? Protože to nemá smysl? Jak to ale zjistit? Proč nemá smysl, aby mělo smysl hledat/dávat něčemu smysl? Nekonečný regres nutí cynika, aby si uvědomil, že se opírá o princip „nesmyslnosti“, který „visí ve vzduchu“, tj. nezdůvodněn. V posledku tedy i cynik něčemu „věří. 
Modifikujme výše uvedené příklady k nastínění morálních postojů SP cynika; první se vztahuje k vnitřní nezměnitelnosti klienta, druhý k vnější:

- SP sice nepopírá, že klient je psychicky nemocný člověk, ale všude, kde může, toho využívá ve svůj prospěch (podle „práva silnějšího“).

- SP sice neusiluje o odebrání dítěte z rodiny tím, že by subjektivní kritéria nadřadil objektivním, ale na druhou stranu se vůbec nesnaží zhoršené podmínky v rodině jakkoli zlepšit, př́p. napomoci ke zlepšení („Vždyt to přece stejně nemá smysl“). Pokud se do případu zapojí další jeho kolegové, kteří jsou fanatiky a svá subjektivní hlediska staví nad objektivní, zůstane neutrální nebo se cynicky přidá na stranu kolegů.

Pravděpodobně žádný správným způsobem angažovaný ${ }^{4}$ SP vědomě nechce být ani fanatikem, ani cynikem. Proč? Protože je nerozumné ignorovat nebo banalizovat to, co nelze změnit. Žádný rozumný člověk nepopře, že je třeba to přijmout. Nebot' i když to budeme ignorovat nebo banalizovat, stejně to nezměníme. Je to součástí reality a rozumně jednat lze jen natolik, nakolik přijmeme realitu a učiníme ji základem svého jednání. Fanatik a cynik tudíž nejednají rozumně.

(c) Stoik se zdá rozumný, protože přijímá vše, co mu život přináší. Řídí se podle hesla: „Chtěj to, co se děje a vždy budeš spokojený. “ Zdá se vyrovnaný a svobodný, ale za cenu, že se zcela vzdal svých emocí. Chtít vždy to, co se děje, totiž implikuje, že to, co se děje a vadí mi, mi vlastně vadit nesmí. Ideálem stoika je proto bezvášnivost. Stoik musí obětovat subjektivní smysl určitému pojetí objektivního smyslu. Stoický objektivní smysl je ale fatalistický: jde o neúprosný zákon, kterému se stoik musí přizpůsobit, „musí jej následovat, musí jej poslouchat. Musí věřit, že se muselo stát všechno, co se děje, a nesmí nic vyčítat... " ${ }^{25} \mathrm{~V}$ morálním ohledu sice stoik usiluje o nadlidskou trpělivost, ale schází mu motivace měnit ty věci, které měnit lze a které je správné měnit k lepšímu. Někteří stoikové dokonce odsuzovali soucit. ${ }^{26}$

SP stoik může být „probuzený“ cynik anebo fanatik vycházející z nějakého druhu fatalismu. „Věří v objektivní smysl života, který sice „funguje“, ale deterministicky a člověku nezbývá, než se mu podřídit (at chce či nechce). SP stoik s nadlidskou trpělivostí snáší u klienta všechno, i to, co by bylo žádoucí změnit, a snaží se nevidět rozdíl mezi tím, co mu vadí a nevadí. Jestliže všechno, co se klientovi stalo, se muselo stát, není jeho stav spravedlivý? SP stoik se může v praxi podobat cynikovi, ovšem s tím rozdílem, že ve fatalistickém dění vidí objektivní smysl. Ten ale nelze měnit, je nutné se mu přizpůsobit. Proč tedy klientovi pomáhat, proč mu pomáhat měnit jeho život? Jestliže SP stoikovi schází morálně relevantní soucit, může to být pro některé druhy sociální práce důležitý nedostatek.

Modifikujme výše uvedené příklady ještě k nastínění morálních postojů SP stoika; první se vztahuje k vnitřní nezměnitelnosti klienta, druhý k vnější:

- SP přijímá klientovu psychickou nemoc, ale nemá s ním vůbec žádný soucit a nesnaží se o zlepšení.

- SP sice neusiluje o nespravedlivé odebrání dítěte z rodiny, ale také nevyvíjí žádné aktivity ke zlepšení zhoršených podmínek v rodině.

24 Podle Karla Kopřivy se právě neangažovaní SP vyznačují tím, že ve své práci nevidí smysl. Srov. Karel KOPŘIVA, Lidský vztah jako součást profese, Praha: Portál, 2006, s. 16. Neangažovaný SP je tedy více či méně cynikem. Fanatikem je naopak takový SP, který ve své práci sice smysl vidí, ale jen ten, který vnáší on sám.

25 SENECA, Další listy Luciliovi, Praha: Svoboda, 1984, s. 232.

26 Srov. Robert SPAEMANN, Moralische Grundbegriffe, s. 104 
Je zřejmé, že stoický morální postoj je ze tří uvedených postojů nejlepší v tom ohledu, že přijímá realitu a učí člověka smírenosti s tím, co nelze změnit a vadí nám. Stoicismus má nicméně, jak jsme viděli, určité nedostatky. Aniž bych si dělal nárok na detailní kritiku stoicismu, přesto bych rád upozornil na dva hlavní nedostatky stoicismu jakožto určitého typu centrálního aspektu spirituality: Stoikové učili, že člověk má jednat $\mathrm{v}$ souladu se svou přirozeností. ${ }^{27}$ Avšak $\mathrm{k}$ lidské přirozenosti patř́i $\mathrm{i}$ vášně. Tedy jednat $\mathrm{v}$ souladu s přirozeností nemưže implikovat bezvášnivost, apatii. ${ }^{28}$ Druhý nedostatek se týká smiŕ̌enosti se vším. Stoikové učili shodě vủle s tím, co s děje. Avšak ne vše, co se děje, je morálně správné. Jestliže nesmíme chtít, co je morálně nesprávné, pak nesmíme chtít vše, co se děje.

\section{Vyrovnaný kirestảan a spolehnutí se na Krista}

S pomocí Spaemannovy typologie jsme nahlédli některé základní souvislosti mezi (ne)hledáním objektivního smyslu života jakožto centrálním aspektem spirituality SP a morálním postojem SP k tomu, co SP nemůže změnit. U fanatika a cynika je místo o „nehledání“ výstižnější hovořit o popření. Proti tomu jsem vznesl námitky výše v pozn. 23 s pomocí nekonečného regresu a naznačil, že spirituální predpoklady beze-smyslu života představují u cynika jakousi „víru“ - v určitý (meta...)meta-beze-smysl, který už nedokazuje, ale v nějž věří. Podobně u fanatika. Fanatik věrí, že objektivní smysl tvoř́ svým subjektivním smyslem, ten však také musí v něčem zakotvit. A protože rovněž nemůže postupovat donekonečna, i on postuluje nějaký subjektivní (meta...) meta-smysl, který už nedokazuje, ale v nějž věríi. ${ }^{29} \mathrm{I}$ když lze fanatismus a cynismus označit jako sekulární spirituality, nahlížíme, že mají i jakýsi (pseudo)náboženský základ.

Stoické přesvědčení je primárně přesvědčením filosofickým, vychází nicméně také z určité „víry“, z panteismu. Stoik, na rozdíl od fanatika a cynika, nepopírá objektivní smysl života. Stoický panteismus ovšem obětuje subjektivní smysl fatalistickému pojetí objektivního smyslu. Stoický objektivní smysl života sice vyžaduje smířenost, avšak za cenu celé řady nedostatkủ. Stoický fatalismus lze také označit za sekulární spiritualitu, ač má rovněž náboženský základ. Jde o „víru“ $v$ „logos“ (rozum), neosobní, věčný, vše-určující princip. Pojem „logos“ př̌ešel z předkřestanské a nekřestanské filosofie do křestanské filosofie a teologie a získal specifický význam tím, že se stal označením pro druhou božskou osobu, Ježíše Krista. V tomto př́padě se ovšem píše s velkým počátečním písmenem - „Logos" (srov. J 1,1). S ohledem na náš kontext je křestanství specifickou sacred spiritualitou, v níz objektivní smysl života pro každého člověka představuje právě Logos. ${ }^{30}$ Podívejme se nyní stručně na základní specifika křestanské smírenosti/vyrovnanosti a spolehnutí se na Krista; nejprve obecně, i skrze srovnání se stoikem, pak na př́kladech z oblasti sociální práce.

Srovnáme-li křestana se stoikem, liší se křestan v tom, že se snaží integrovat vášně/emoce. Kultivuje je s pomocí rozumu a vůle, nespoléhá ovšem jen na přirozené světlo rozumu, ale i na nadpřirozené, tj. na víru, na světlo Ducha svatého. ${ }^{31}$ Vůle se řídí rozumem (úsudkem svědomí) a společně

27 SENECA, Dalši listy Luciliovi, s. 232.

28 Srov. Robert SPAEMANN, Moralische Grundbegriffe, s. 104. Vášně/emoce je ovšem třeba správně formovat rozumem, jak upozorňoval již Aristoteles.

29 Tím ovšem nechci říci, že každý nekonečný regres lze vyřešit jen „vírou“v nějaký první princip. „Vírou“ (v uvozovkách) označuji případ, kdy se nějaký první princip slepě přijímá, aniž by se kriticky prověřil. Z filosofického hlediska je možné a žádoucí, aby se i první principy dokazovaly, a sice tzv. neprrímým důkazem.

30 Křestanská filosofie a teologie je specifická také tím, že objektivní smysl života není primárně člověkem „objeven“, ale člověk je objektivním smyslem jakožto Logem „osloven“. To však nutně neznamená na straně člověka úplnou pasivitu.

31 Duch svatý je třetí božská osoba, vedle Otce a Syna (Ježíše Krista - Logos). Otec je Počátkem (křestanské) existence. Z Otce a Syna vychází Duch svatý. Podle křest’anské teologie ovšem všechny tři božské Osoby sdílejí jednu přirozenost (jsou jedním Bohem) a tudíž působí vždy společně. 
mají k dispozici tři teologální ctnosti - víru, naději a lásku. Jedná se o ctnosti „vlité, tj. takové, které křestan nemůže získat jen přirozenou silou. Tři teologální ctnosti pomáhají zdokonalovat čtyři přirozené ctnosti - moudrost, spravedlnost, statečnost a umírněnost. Podle toho, nakolik má zdokonalených těchto sedm ctností, přistupuje křestan i k tomu, co nemůže změnit a vadí mu. Rozhodně neusiluje jako stoik o zrušení rozdílu mezi tím, co mu vadí a nevadí. Ve světle moudré víry se postupně učí rozlišovat, co mu (ne)má vadit a v jakém pořadí. Křestan není vyrovnaný tak, že by mu bylo lhostejné, zda se mu podaři realizovat vlastní záměry, nesnaží se o apatii (bezvášnivost) jako stoik. Na druhou stranu ale ani neprosazuje jako fanatik realizaci vlastních zámérů za každou cenu.

Z vnějšího pohledu se může křestan velmi podobat stoikovi v tom, že mu postupně mnoho nezměnitelností přestane vadit. Avšak jádro rozdílu spočívá v tom, že křest’an není apatickým, nýbrž v síle Ducha svatého schopným (některé) obtížné a bolestivé věci snášet. Pro křestanskou smířenost je specifický nový druh nadpřirozené motivace a nadpřirozené síly snášet to, co nelze změnit. Křestan by ovšem neměl být trpitelským bolestínem; pokud je to možné, snaží se v normálním případě bolest, utrpení a zlo odstranit (a modlí se za to), ale když to možné není, snaží se podle vzoru Krista o přijetí a vyrovnanost (srov. L 22,42). ${ }^{32}$ Křestanova (snaha o) smírenost s celoživotními/dlouhodobými nezměnitelnostmi, které mu vadí / působí bolest je př́mo úměrná křestanově víre a dưvěre, že Bůh hlídá jejich intenzitu i extenzitu a má dobré(!) důvody, proč je dopouští (srov. $1 \mathrm{~K} 10,13) .{ }^{33}$ A schopnost toto vše snášet je př́mo úměrná síle křestanovy (nadpř̀irozené) lásky (srov. $1 \mathrm{~K} 13,7) .^{34}$

Čím je v této souvislosti křestanovo spolehnutí se na Krista? Je především zmíněnou vírou a důvěrou, tj. ve své podstatě úkonem rozumu a následným souhlasem vůle. Toto spolehnutí se na Krista se postupně stává trpělivostí, statečností a promítá se do dalších ctností. Klíčové je, že s ohledem na ty dlouhodobé/krátkodobé nezměnitelnosti, které se křestan po zralé úvaze a modlitbě pokusil změnit, ale nebylo to možné, se spolehnutí na Krista eo ipso stává současně trpěním s Kristem. Na rovině rozumu jde tedy o spolehnutí se na Krista, že On propůjčuje daným nezměnitelnostem smysl (i když v nich křest̉an třeba momentálně smysl nevidí!), na rovině vưle, emocí a celkově těla jde o snášení daných nezměnitelností s Kristem, v síle Jeho Ducha. V tomto hlubokém významu je křestanská spiritualita právem chápána nejen jako to, co koná křestan sám, ale rovněž jako to, co v křestanovi koná Duch svatý! ${ }^{35}$ Přesto ale nejde o pouhou pasivitu, a tak je i snášení a trpění určitou formu jednání. ${ }^{36}$ Poměr mezi pasivitou a aktivitou může být různý, avšak nikdy nejde o fatalistickou pasivitu, naopak, křestan může trpět i aktivně, v naznačeném hlubokém významu - a tím paradoxně dospět k hlubokému vnitřnímu klidu i uprostřed velkých bolestí a protivenství. Poměr mezi objektivním a subjektivním smyslem je proto u křestana jiný než u stoika. Křestan ve vědomí křestanské svobody (srov. $1 \mathrm{~K} 3,21-23$ ) 37 přistupuje ke svému životu a světu aktivně, beze strachu a v důvěře v Boží moc, avšak zároveň přijímá vše, co nemohl změnit, jako Boží nabídku k utrpení s Kristem (což je také proměna světa, alternativní, hlubší). Mezi subjektivním smyslem, kterým disponuje křestan, a objektivním, kterým disponuje (a je) Kristus, panuje dialog. Křestan si nemyslí, že by teprve on vnášel do světa smysl, na druhou stranu si ale také nemyslí, že by

32 „Otče, chceš-li, odejmi ode mne tento kalich, ale ne má, nýbrž tvá vưle se staň.“

33 „Nepotkala vás zkouška nad lidské síly. Bůh je věrný: nedopustí, abyste byli podrobeni zkoušce, kterou byste nemohli vydržet, nýbrž se zkouškou vám připraví i východisko a dá vám sílu, abyste mohli obstát."

34 „At̉ se děje cokoliv, láska vydrží, láska věří, láska má naději, láska vytrvá.“

35 Srov. Vojtěch KOHUT, Spiritualita, in: Stefano DE FIORES - Tullo GOFFI (ed.), Slovník spirituality, Kostelní Vydř́: Karmelitánské nakladatelství, 1999, s. 905.

36 Srov. Robert SPAEMANN, Moralische Grundbegriffe, s. 101.

37 „V̌̌echno je vaše, (...), at svět nebo život nebo smrt, př́itomnost nebo budoucnost, všechno je vaše, vy však jste Kristovi a Kristus je Boží.“ 
stačilo nechat se pasivně vést Bohem jako loutka. Jedná se o živý dialog, vztah, mnohdy i „zápas s Bohem", něco principiálně jiného než stoikova snaha o harmonizaci s neosobním logos. K tomu je vhodné dodat, že opravdová a v praxi žitá křest’anská spiritualita není nikdy záležitostí jen rozumovou (intelektuální) a/nebo pocitovou, zážitkovou apod., ale zahrnuje všechny dimenze osoby, postupně naplňované Duchem Božím. ${ }^{38}$

Jak se projevuje vyrovnanost/smírenost SP křestiana? Vrátíme-li se ke dvěma výše uváděným př́ikladům, můžeme jeho morální postoje nastínit zhruba takto:

- SP přijímá klientovu psychickou nemoc, snaží se s klientem mít soucit a usiluje o adekvátní prrístup ke klientovi.

- SP neusiluje o nespravedlivé odebrání dítěte z rodiny a vyvíjí aktivity na zlepšení zhoršených podmínek v rodině.

Tyto jednoduché ilustrativní příklady doplním dvěma zajímavějšími, které vychází z mé vlastní zkušenosti sociální práce. Snad skrze ně lépe vyniknou některé souvislosti mezi spolehnutím se na Krista a morálním postojem $\mathrm{k}$ tomu, co nelze změnit a je obtížné.

O klienta s Alzheimerovou chorobou v pozdním stadiu se SP stará jako o malé dítě, včetně osobní hygieny. Klient je v pozdním stadiu neurodegenerativního onemocnění mozku a přestal zcela komunikovat. Během pravidelné osobní hygieny ve sprše klient často neudrží stolici, a protože už není schopen vůbec komunikovat, SP je situací vždy poněkud zaskočen a je pro něj psychicky i lidsky náročná. Tato situace nastává často, nelze ji snadno předcházet a představuje pro SP nezměnitelnost, která mu velmi vadí. Z přirozeného, lidského hlediska se SP snaží situaci racionalizovat, klientovi nic nevyčítá a je si vědom, že klient kvůli své nemoci není situací vinen. To však celou situaci SP př́liš neulehčí, a tak SP jakožto křestan spoléhá na nadpřirozenou sílu, která jedině mu pomůže, aby snášel opakující se situace s trpělivostí a smířeností. Jde o postupný proces, morální zrání na hlubší rovině, kdy se SP učí celou svou bytostí spoléhat na Krista, který podpírá jeho omezené lidské síly. Centrální aspekt spirituality SP, věřit, že situace má objektivní hlubší smysl, má rozhodující roli jak pro samotné započetí procesu, tak pro jeho úspěšné trvání. SP působící jako streetworker v církevní organizaci Teen Challenge kontaktuje drogově závislého klienta a nabízí mu residenční jednoletý léčebný program, v jehož rámci má klient šanci se závislosti zbavit, resp. začít celkový proces psychofyzického uzdravování. Léčebný program probíhá $\mathrm{v}$ křestanském prostředí. Klient to ví, ale právě proto jej odmítá a nevybíravými, hrubými invektivami se vymezuje proti křestanství. To SP vadí, nebot' je křestan. SP na jednu stranu nechce klienta primárně „obracet na křestanstvi“, na druhou stranu jej ale také nechce ponechat v závislosti a ví, že nabízený program by pro klienta mohl být životní šancí. Invektivy během dalších setkání však pokračují. SP si je vědom toho, že může nabídnout klientovi jiné formy léčby závislosti, ale vnitřně tuší, že invektivy klienta a jeho odpor vưči křestanství jsou pravděpodobně jen pózou zakrývající spirituální sensibilitu klienta pro právě nabízený druh programu. SP však neví, jak tuto sensibilitu aktivovat a nasměrovat správným směrem, zároveň mu vadí invektivy klienta a jeho hrubý způsob komunikace. Zdá se, že z čistě přirozeného hlediska není SP morálně povinen snášet klientovy invektivy a hledat složité cesty ke klientově spirituální senzibilitě. Na druhou stranu

38 Srov. Walter H. PRINCIPE, Spirituality (Christian), in: Michael DOWNEY (ed.), The New Dictionary of Catholic Spirituality, Collegeville: The Liturgical Press, 1993, s. 931. Co se týká křestanské spirituality, musím upozornit, že jsem se pokusil opravdu jen velmi stručně naznačit některé její podstatné znaky. Už v rámci samotné katolické spirituality nalezneme obrovské množství různých spiritualit (řádových, kněžských, laických), z nichž některé se větví do dalších druhů a podob. Pluralita spiritualit v rámci (katolického) křestanství je však žádoucí a dokonce nutná, protože jde o různá charizmata a projevy téhož Ducha svatého s ohledem na různé doby, potřeby a okolnosti. 
ale jako křestan věří ve skrytý, nadpřirozený smysl situace, snaží se o trpělivost a vyrovnanost. Postupně hledá složité cesty ke klientově duši a snáší jeho způsob komunikace. Morálně se opírá o centrální aspekt své spirituality, vidí v situaci objektivní, skrytý smysl.

\section{Závěrem}

Spiritualita má integrující, ale i destruktivní potenciál. ${ }^{39}$ Tímto shrnujícím postřehem vyjadřuji zároveň hlavní závěr tohoto článku. Doufám, že čtenář nahlédl sílu onoho potenciálu během zkoumání souvislostí mezi zvoleným centrálním aspektem spirituality SP - (ne)hledáním objektivního smyslu života - a morálním postojem SP k tomu, co nemůže změnit a vadí mu.

SP fanatik jedná s klientem destruktivně. Domnívá se, že smysl klientova života tvoří pouze svým nasazením pro klienta. Objektivní realita i její smysl mu uniká. Má velké problémy přijmout všechny druhy nezměnitelností klienta, jež mu vadí. Manipuluje klientem podle svých subjektivních představ. SP cynik jedná s klientem rovněž destruktivně, i když je to snad méně nápadné. Cynikem se SP může stát, když se předtím jako fanatik vyčerpal neuváženými změnami nezměnitelností, jejich popíráním či manipulativním jednáním. Věří v právo silnějšího, na objektivní realitu však nahlíží jako na mechanické dění, jež postrádá jakýkoli smysl. Zatímco fanatik tenduje k morálnímu subjektivismu, cynik k morálnímu nihilismu. Cynik bývá zpravidla v hloubi duše přesvědčen, že pomáhat klientovi vlastně nemá smysl. Často klienta využívá ve svůj prospěch. Většina SP se s nejvyšší pravděpodobností shodne na tom, že morální postoje fanatika a cynika jsou postoji nerozumnými, profesně i lidsky neperspektivními.

SP vyrovnaný stoik může být pro některé na první pohled přitažlivým typem, pravděpodobně kvůli apatické neotřesitelnosti a nadlidské trpělivosti. Ve skutečnosti bude ale morální postoj stoika přijatelný jen pro toho SP, jenž důsledně zastává nějaký fatalistický životní postoj a neklade (žádný) důraz na soucit. Soucit se však zdá být pro sociální práci důležitý. Na typu stoika jsem se pokusil ukázat, jaký ústřední vliv na spiritualitu mají ty prvky světonázoru/náboženství, jež vysvětlují otázku objektivního smyslu života a otázku po povaze nejvyššího principu kosmu. SP vyrovnaný křestan se zvnějšku může velmi podobat stoikovi, avšak mezi nimi je podstatný rozdíl právě v tom, že křestian žije svou spiritualitu ve vztahu k Bohu, který není pouhým neosobním principem kosmu. Morální postoj SP křestana bude asi plně pochopitelný jen pro ty SP, kteří jsou sami křestany nebo křestanství více znají.

Čtenář, který není křestanem, může namítnout, že SP vyrovnaný křestan hraje v tomto článku roli jakéhosi „SP-supermana“. SP vyrovnaný křestan je představen jako nejlepší typ, v rámci zvolených př́kladů nejlépe morálně hodnocen. To je pravda. Na druhou stranu bych rád upozornil, že použitá typologie je normativně ideální. V reálné praxi nemusí být (a někdy také není) SP křestan morálně hodnocen jako nejlepší. V reálné praxi může být i SP křestan ohrožen či dokonce „infikován“ fanatismem, fatalismem či cynismem. Některé rysy SP křestana tendujícího k fanatismu najdeme v pozn. 16. Kromě toho je třeba doplnit, že použitá typologie nepokrývá celou pestrou realitu a jistě není úplná. Bylo by zajímavé doplnit další typy z pohledu dvou ostatních monoteistických náboženství, judaismu a islámu, př́íp. z pohledu hinduismu a buddhismu. To však bohužel přesahuje rozsahové možnosti článku.

I přes tato omezení může být předložený článek pro některé české SP dobrým nástrojem sebereflexe několika základních souvislostí mezi (ne)hledáním objektivního smyslu života a morálním

39 Srov. Zdeněk VOJTÍŠEK, Vybrané teoretické podněty, in: Zdeněk VOJTÍŠEK - Pavel DUŠEK - Jiří MOTL, Spiritualita v pomáhajících profesích, s. 80 . 
postojem k tomu, co nelze změnit a pưsobi obtiže. Při tom je třeba mít na paměti, že primárně nejde o označení sebe či druhých jedním $z$ předložených (nebo jiných) typů. Typologie mají napomáhat konkrétním osobám při sebereflexi. A sebereflexe pak má být kognitivním východiskem pro žádoucí změnu praxe. Doufám, že článek bude v českém prostředí (křestanské) teorie sociální práce tomuto účelu úspěšně sloužit a že bude využit, př́íp. doplněn a/nebo kriticky reflektován.

V úvodu jsem citoval výzvu jedné nedávné české empirické studie, která se zabývala výzkumem fenoménu spirituality mezi studenty sociální práce. Šlo o výzvu pro akademické pracovníky: Nebát se hovořit o spiritualitě se studenty sociální práce a najít způsob, jak začlenit relevantní témata do vzdělávacího kurikula. Tímto článkem jsem se na ni pokusil odpovědět. Obsah tohoto článku použiji jako výchozí text přednášky pro studenty v navazujícím magisterském oboru Etika v sociální práci.

\title{
Proč jedná sociální pracovník fanaticky, cynicky, nebo vyrovnaně? K souvislostem mezi spiritualitou a morálním postojem $\mathrm{k}$ tomu, co nelze změnit
}

\begin{abstract}
Abstrakt
Autor vychází z rešerše relevantních českých zdrojů a přispívá do české odborné diskuse na téma spiritualita a sociální práce příspěvkem vycházejícím z křestanské filosofie a teologie. Autor zkoumá některé základní souvislosti mezi vybraným centrálním aspektem spirituality sociálního pracovníka a morálním postojem sociálního pracovníka k tomu, co nemůže změnit a vadí mu; jde o aspekt hledání objektivního smyslu života. Autor ukazuje souvislosti s pomocí vybrané typologie - fanatik, cynik, vyrovnaný stoik a vyrovnaný křestana a nabízí sociálním pracovníkům a studentům sociální práce inspirativní typologický nástroj k sebereflexi. Obecné analýzy jsou ilustrovány jednoduchými př́íklady vycházejícími i z autorovy vlastní zkušenosti. Hlavní závěr zní: Spiritualita sociálního pracovníka má v jeho morálním postoji k tomu, co nemůže změnit a vadí mu, integrující, ale i destruktivní potenciál. Destruktivní potenciál mají spirituality fanatika a cynika. Nakolik Ize mluvit o integrujícím potenciálu u spirituality vyrovnaného stoika, záleží na pohledu čtenáře. Podle autora má však největší integrující potenciál spiritualita vyrovnaného křestana.
\end{abstract}

Klíčová slova: křestanství a sociální práce, sociální práce a spiritualita, smysl života, fanatismus, cynismus, stoicismus

\section{Kontakt na autora \\ PhDr. Vojtěch Šimek, Th.D.}

Jihočeská univerzita v Českých Budějovicích

Teologická fakulta, Katedra filosofie a religionistiky

Kněžská 8, 37001 České Budějovice

simekv00@tf.jcu.cz 